\title{
Integrating Remote Sensing, GIS, Census, and Socioeconomic Data in Studying the Population-Land Use/Cover Nexus in Ghana: A Literature Update
}

\author{
Samuel Nii Ardey Codjoe*
}

\begin{abstract}
Land is a very important asset and a means to sustain livelihood. In the face of a rapidly growing global population, increase in technological capacity, and affluence, the earth's land cover has been transformed, especially in developing countries. At the same time, social organisation, attitudes, and values have also undergone profound changes. In contemporary times, issues of sustainable development, pollution prevention, global environmental change and related issues of human-environment interaction have been a major concern globally. This concern has largely been sparked by the phenomenon of global warming and its consequences, which are threatening the very existence of humans on the surface of the earth. Remotely sensed data (mainly from aerial photographs and satellite images) in combination with Geographical Information Systems (GIS) have been observed to have potential scientific value for the study of population-environment interaction. This paper provides an account of how Remote Sensing, GIS, census (mainly population and agricultural) and socioeconomic (household, district and regional) survey data have been integrated in studying the population land-use/cover nexus in Ghana. It also identifies the major methodological challenges, and solutions.
\end{abstract}

\section{Résumé}

La terre constitue un atout majeur et un moyen de subsistance. Devant une population mondiale qui ne cesse de croître de manière rapide, devant une croissance des capacités technologiques et des richesses, on assiste à une modification de la couverture terrestre dans le monde, en particulier dans les

* Regional Institute for Population Studies, University of Ghana, P. O. Box LG 96, Legon, Accra, Ghana. E-mail: scodjoe@ug.edu.gh 
pays en développement. Simultanément, les structures, les attitudes et les valeurs sociales ont aussi subi de profondes mutations. Aujourd'hui, les questions de développement durable, de prévention de la pollution, de changement de l'écologie mondiale et autres problèmes liés à l'interaction de l'homme avec l'environnement constituent une préoccupation majeure dans le monde. Cette préoccupation est suscitée par les phénomènes tels que le réchauffement de la terre et ses conséquences qui sont une menace à l'existence même de l'être humain sur terre. On a constaté que les données de télédétection (en provenance, en majeure partie, de photographies aériennes et d’images prises par satellites) combinées aux Systèmes d'information géographique (SIG) ont un potentiel de valeur scientifique sur l'étude de l'interaction des populations avec l'environnement. L'auteur fournit un rapport détaillé sur la façon dont les données recueillies grâce à la Télédétection, les SIG, les recensements essentiellement démographiques, agricoles et socioéconomiques (à la suite d'enquêtes menées auprès des ménages, des districts et des régions) ont été intégrées dans l'étude de la relation entre l'utilisation des sols par les populations et la couverture terrestre au Ghana. Les principaux défis méthodologiques et leurs solutions ont été également identifiés.

\section{Introduction}

Land is a very important asset and a means to sustain livelihood. It is the key and finite resource for most human activities including agriculture, industry, forestry, energy production, settlement, recreation, and water catchments and storage. Land is a fundamental factor of production, and through much of the course of human history, it has been tightly linked to economic growth. It comprises biophysical qualities such as soil, topography, climate, geology, hydrology, biodiversity and political divisions. Land is also defined as consisting of such socioeconomic factors as technology and management. Land use has been defined as the way in which, and the purposes for which, humans employ the land and its resources (Meyer 1995). Land cover on the other hand has also been defined as that which overlays or currently covers the ground, especially vegetation, permanent snow and ice fields, water bodies or structures (USDA Forest Service 1989).

In the face of a rapidly growing global population, increase in technological capacity and affluence, the Earth's land cover has been transformed especially in developing countries. At the same time, social organisation, attitudes, and values have also undergone profound changes. In contemporary times, issues of sustainable development, pollution prevention, global environmental change and related issues of human-environment interaction have been a major concern of the global scientific community as well as citizens and policy makers of the world. This concern has largely been sparked by the phenomenon of global warming and its consequences, which are threatening the very existence of humans on the surface of the earth. In 
understanding global environmental change, a consideration should be made to the conditions and changes in land cover engendered by changes in land use; the rates of change in the conversion, modification and maintenance processes of use; and the human forces and societal conditions that influence the kinds and rates of the processes (Lambin et al., 1999).

Even though remote sensing is not a new technology, since aerial photographs have been in widespread use for a half-century (Carls 1947) and satellite images for a quarter-century (Estes et al., 1980), remotely sensed data have been observed to have potential scientific value for the study of human-environment interaction, especially land use/cover changes and have therefore been identified as a useful tool to aid the process of understanding human-environment interaction (Dale et al., 1993). Furthermore, remote sensing and global positioning systems (GPS) have given rise to the advent of more precise and geographically referenced data on cover and use of land, which in turn have created opportunities for improved assessments and analysis. With the aid of these new data, researchers have now started to unravel the processes that drive the cycle of land use change and resource degradation. Airborne and satellite remote sensing data have been proven to be one of the best techniques for monitoring forest clearing, shifting cultivation, and land use conversion patterns and has therefore been partnered with socioeconomic surveys and censuses as well as other biophysical information gathering techniques, to bring about a better understanding of land use/cover dynamics and the factors that drive them (Quattrochi and Goodchild 1997).

Remote Sensing is particularly very useful for population studies and the following are a few of them. Jensen and Cowen (1999) for example, identify three ways in which population estimates can be attained through Remote Sensing. These are (i) individual dwelling units count (ii) measuring urban extent and (iii) land use/cover classification. Remote Sensing can also provide intercensal population estimates. For instance night-time lights have been used as a proxy to estimate population (Mathur 2002). Finally, remote sensing can also assist in planning censuses by identifying areas of new development and provide regular updates of new housing stock for planners. This paper provides a literature update on how Remote Sensing, GIS, census and survey data have been integrated in studying the population landuse/cover nexus in Ghana. It also identifies the major methodological challenges, and suggested solutions provided by some researchers in this new area of scientific enquiry.

\section{Studies in developing countries}

Extensive studies on the human dimensions of global change have been undertaken by the Land Use/Cover change (LUCC) project of the International 
Geosphere-Biosphere Programme and the International Human Dimension Programme on Global Environmental Change. These studies have focused largely on indirect linkages between information embedded within spatial imagery and the core themes of the social sciences. These works are exemplified by assessments of the proximate causes of land use/cover change (for example, slash-and-burn cultivation, clear cutting of timber), environmental constraints/opportunities associated with human activities (soil sustainability and zones of intensive cultivation), or assessment of infrastructure in planning (for example,, green spaces, road networks) (Ehrlich et al., 1997).

Other researchers have also used remote sensing data to analyse population and land use/cover change in many parts of the developing world. Notable among these areas are the Nang Rong district of Thailand (Entwisle et al., 1998), the Amazon Region of South America (Skole and Tucker 1993; Moran and Brondizio 1998 and Pfaff 1997), the Peten in Guatemala (Sever 1998), the Chittagong Region in Bangladesh (Rahman and Csaplovics 1999), Costa Rica (Veldkamp and Fresco 1997), Ecuador (Koning et al., 1999), China (Verburg et al., 1999a), Java in Indonesia (Verburg et al., 1999b), and Jordan (Millington et al., 1999). The most extensive studies in sub-Saharan Africa using a combination of satellite and survey data to study the socioeconomic drivers of land use and cover change are the ones by Guyer and Lambin (1993), Mertens and Lambin (1997) and Mertens et al (2000).

\section{Trends in Ghana}

Ghana has a surface area of about 238,533 $\mathrm{km}^{2}$. In 1921, the country had a population of 2.2 million, which almost doubled within a period of 27 years, reaching 4.1 million in 1948. The population from then increased rapidly between 1948 and 1960, rising to 6.7 million. The 1970 census put the country's population at 8.6 million while in 1984, 12.3 million people were counted in the country. By the year 2000, Ghana's population had reached 18.9 million and projections show that it is currently about 20 million. The annual growth of the population has been recorded to be 2.4 percent during 1960-1970, 2.6 percent in 1970-1984 and 2.7 percent between 1984 and 2000. Ghana's population can therefore be said to have grown at a high rate of 2.6 percent since 1960 (GSS 1989 and 2002). The current rate of population growth suggests that Ghana's population would double within the next 27 years and there is therefore little or no sign to show that Ghana's population growth rate has declined in recent times. Due to rapid population growth, population density rose from 28 persons per $\mathrm{km}^{2}$ in 1960 to 39 persons per 
$\mathrm{km}^{2}$ in 1970. In 1984 it was 51 persons per $\mathrm{km}^{2}$ and in 2000 it reached 79 persons per $\mathrm{km}^{2}$.

The demographic trend in Ghana since 1970 can be said to have been that of a high but moderately declining fertility and a declining mortality. Total fertility rate (TFR) has declined from a high of around 7.4 children per woman in the 1960s (Caldwell 1965) to 6.4 in 1988. In 1993, TFR was recorded as 5.5, which further declined to 4.6 in 1998 and 4.4 in 2003, i.e. a reduction of two children per woman within a period of 15 years (GSS 1999 and 2004). Cultural beliefs and practices that encourage large family sizes and low modern contraceptive use are mainly responsible for the fertility rates among different population sub-groups in the country. Due to the issues mentioned, crude birth rate (CBR) has been high at about 45 per 1000 population in the 1960s and 1970s with marked declines observed only during the 1990s.

Mortality trends have also shown some steady improvements over the years. Infant mortality has declined from a level of 77 per 1000 live births in 1988 to 66, 57 and 64 per 1000 live births in 1993, 1998 and 2003, respectively. In the same way, overall under-five mortality, which was 155 per 1000 live births in 1988, declined to 119 in 1993, 108 in 1998 and 111 in 2003. This has all culminated in a steady decline in crude death rate (CDR). CDR which stood at about 23 per 1000 population in the 1960s, steadily declined to as low as 10 per 1000 population (Population Reference Bureau 2004). The fertility and mortality situation in the country implies that the natural population increase has shot up following a widening gap between fertility and mortality.

As far as migration is concerned, the trend and pattern in the country during the 1960s was more of rural-rural movements. This was as a result of the cocoa boom, where most of the forest areas in Ashanti, Eastern, Western and Brong Ahafo Regions became important receiving areas for migrants mainly for cocoa and other cash crop production. The pattern of internal migration, however, changed in the mid-1970s towards the cities and large towns. According to the 1984 population census, in terms of volume, internal migration was 35.3 percent urban-urban, 25.3 percent urbanrural, 22.9 percent rural-rural and 16.6 percent rural-urban. On the international migration front, the contribution to Ghana's population growth has not been that much. Cross-border population movements between Ghana and her neighbours, i.e., Côte d'Ivoire, Togo and Burkina Faso have constituted the main sources of international migration in Ghana. Another aspect of this phenomenon is the crossing of herdsmen from the neighbouring countries, particularly Burkina Faso, into Ghana with large numbers of their cattle dur- 
ing periods of drought. Finally, a number of refugees from the West African sub-region, particularly, from Liberia and Sierra Leone following the civil wars in those countries, have also migrated to Ghana.

\section{Population growth and land degradation in Ghana}

Rapid population growth and low economic standards of living in Ghana have brought in their wake a lot of consequences for agricultural land and forest resources. As Benneh and Agyepong (1990) put it, among the three factors that have contributed to greater competition for land, hitherto covered by trees and now devoid of vegetation, one is demographic pressures. In their opinion, as population increases, so too does the need for land, to expand settlement infrastructure and other utilities. Furthermore, there has been increasing use of fuelwood in both urban and rural areas in Ghana, as it is the cheapest form of energy. Faced with development constraints, including low incomes, shifts from the use of fuelwood to use of cleaner fuel alternatives such as electricity, kerosene, and Liquefied Petroleum Gas (LPG) have not been possible. While large areas continue to be depleted, the trend of fuelwood use has been increasing in Ghana. Between 1966 and 1975, countrywide fuelwood consumption increased at the rate of 5.8 percent per annum (Ardayfio-Schandorf 1986).

A 1988 study of charcoal production and use in Ghana indicated that over 500,000 metric tonnes of charcoal are consumed annually (Nketia et al., (1988). This translates into more than 3.6 million tonnes of wood extracted each year from forests and farmlands for charcoal production. Corresponding estimates for fuelwood consumption indicate that an annual total of 5.83 million tonnes of wood are cleared. Put together, the total amount of wood cleared to meet Ghana's annual fuelwood needs is equivalent to over 650,000 hectares of forest land (ERG Bulletin 1989). Furthermore, Benneh and Agyepong (1990) estimated an annual domestic consumption of 5,547,200 $\mathrm{m}^{3}$ of fuel wood and 1,992,400 $\mathrm{m}^{3}$ of charcoal in Ghana. Alhassan (1993) also found that per capita fuelwood consumption in Ghana in both urban and rural areas increased from $485 \mathrm{~kg}$ per capita in 1980 to about $525 \mathrm{~kg}$ per capita in 1993. These figures are well above the growth of wood stock (Tufour 1989), and deforestation and energy problems could even get higher with time unless the trend is halted. The annual rate of deforestation in Ghana was estimated to be 1.72 percent or 120,000 hectares during the period 1990-2000 (FAO 2000). In the opinion of Nketia et al. (1988), Ghana's dependence on fuelwood is a large factor behind the deforestation witnessed in recent times. 
Due to wasteful and uncontrolled forms of logging in Ghana, the country is increasingly under the threat of desertification. The northwestern section of Upper West Region, the eastern half of Northern Region and parts of Upper East Region are at the highest risk. Also, deforestation has led to increased soil erosion and loss of reliable water supply, all of which has brought about a marked decrease in agricultural productivity and a lowered standard of living among the population. As a result of rapid population growth, conflicts over land have been rife in Ghana, assuming various dimensions from minor conflicts between individuals and families to large-scale ones between ethnic groups. The northern parts of the Volta Basin in Ghana constitute an area plagued with ethnic conflicts. Bloody conflicts, which have brought in their wake devastation of groups of people and in some instances desolation of entire settlements, have raged between the Nanumba and Konkomba (1980), Gonja and Vagla (1984), Konkomba and Bimoba (1990) and Nawuri and Gonja (1991). The loss of lives and property that is associated with such conflicts over land, places a great socioeconomic burden on the nation's scarce resources and, consequently, hampers development.

\section{Remote sensing in Ghana}

Prior to 1901, there were only few survey and mapping activities. The first survey institution, the Mines Survey Department, was established in 1901, but the Survey Department itself was set up in 1908 (Abu and Brimah 1989). Aerial photography can be said to have begun in Ghana in earnest about 1946 with coverage of a small area on the dip slopes of the Kwahu Scarp around Abetifi by the then Royal Air Force. According to Amatekpor (1999), a land use map of Ghana was not available until 1998. In his opinion, the land use map of Ghana, which was available in 1959, was not only obsolete, but also of little or no value for intensive land use planning. He further mentioned that the development of Remote Sensing and Geographic Information Systems (GIS) technology enabled Ghana to complete in 1998 a detailed land use/ cover map of the whole country at a scale of 1:250,000 under the Ghana Environmental Resource Management Programme (GERMP). Until 1956, only small areas (southwestern coast, Nsaba cocoa growing area and parts of Mamprusi) were covered mainly for specific investigation such as oil exploration, agricultural census and land use planning. However, since 1972, satellite remote sensing coverage of Ghana has been available (Agyepong 1989), and remote sensing technology has been applied to a great deal of natural resource management research in Ghana. Some of these are: soil resources inventory (Agyili 1989), water resources research (Amuzu 1989), forest inventory (Agurgo 1989), disaster management (Kyem 1989), land use inventory and mapping (Duadze et al. 1999), environmental monitoring 
(Amamoo-Otchere 1989), geological problems (Adjei 1989), rainfall calibration (Kakane and Hooijer 1999), road map updating (Mensah and Nyamekye 1999), and groundwater exploration (Banoeng-Yakubu 1999).

Although this began later, Ghana has benefited from a few studies that combine Remote Sensing/GIS technology, censuses and socioeconomic surveys to study the population-land use/cover nexus. For example, Benneh and Agyepong (1990), used a combination of the two methods to conclude that population increase, development policies, urbanisation and settlement expansion, logging, agricultural land use including wood fuel demands, have among others contributed to greater competition for land, leaving areas formerly covered by trees devoid of vegetation and subsequently leading to woodfuel scarcity.

Kufogbe (1999) used a digital analysis of time sequential SPOT-XS images and the Makov chain model to assess the changes in the land use/cover over the period 1988 and 1994 in the Afram plains of Ghana. His results indicate that the dominant land cover comprises wooded savanna and transition forest. According to him, deforestation in the plains is indicated by various stages of forest re-growth, which have been associated with decline in cocoa cultivation from the beginning of the 1980s.

Braimoh (2004a) investigated the impact of seasonal migration on landuse/land-cover change in an area within the Volta Basin of Ghana. It was revealed that the most drastic land-cover change involved the conversion of woodland to agricultural land, while there was also a general transition to less vegetation cover. Socioeconomic surveys revealed that most of the migration occurred during the post-structural adjustment period in Ghana with declining soil fertility accounting for the highest percent of causes of migration. Multiple regression results highlighted the role of population size and distribution, marketing of agricultural produce and technological evolution of the household in determining agricultural land-use change.

Braimoh (2004b) further identified land use/cover change in a 5,400 km² area within the Volta Basin of Ghana using multi-scale, spatial statistical analyses and household surveys. Land cover change trajectories were also defined using multi-temporal Landsat TM images acquired in 1984, 1992 and 1999. Results show that the dominant land-cover change process was conversion of natural vegetation to cropland, which occurred at an annual rate of five percent between 1984 and 1999. Furthermore, linear multiple regression identified increase in household size, frequency of tractor use, proportion of rice marketed, child dependency ratio, labour availability and distance from localities to the main market, as the major factors determining the amount of land a household cleared for agriculture. It was concluded that the choice of an appropriate scale for land use/cover change models to sup- 
port land-use planning requires a trade-off between spatial detail and extent. At the scale of individuals, households and commercial farmers (30 m $1050 \mathrm{~m}$ ), land use change processes are highly heterogeneous, requiring a large amount of data for characterisation. It was recommended that future land change models should be based on $3 \mathrm{~km}$ to $7 \mathrm{~km}$ spatial scales.

Codjoe (2004) used geo-corrected LANDSAT satellite images for 1991 and 2000 and the population censuses of Ghana for 1984 and 2000 to assess the effect of population change on forest cover between 1990 and 2010 in the Volta River basin of Ghana. Population data, which were available at the local council level, were matched with forest cover at the local council level. The forest cover information was derived from land cover maps of 1990 and 2000. A local council map of Ghana was superimposed on the forest cover map using GIS applications. Proportions of forest cover for each local council were then determined and converted to actual area extent in hectares. Association between forest cover and population for 2000 was then determined from a simple regression model and was used to predict the effect of population growth on forest cover in the various local councils in 2010.

The projected population for each local council for 2010 was inputted into the simple regression model. Together with the constant, the required forest cover in 2010 was determined. Predictions show that the Jaman and Brekum local councils areas that fall within the Black Volta sub-basin and the Kete-Krachi local council in the Daka sub-basin will have depleted forest cover in 2010, as a result of increases in population density. Finally Duadze (2004) also used a combination of LANDSAT satellite images for 1986, 1991 and 2000 and population census reports of Ghana in a study in the Upper West region of Ghana. Results show that population increased from 1984 to 2000 by 32 percent. Since a high proportion (75 percent) of the economically active population were farmers, it was concluded that population played a role in land degradation. Declining soil fertility in the farmlands and increasing population, therefore, caused pressure on land, which led to land degradation. This in turn caused the farmers to move to other areas to farm. This practice was argued to have resulted in progressive loss of woodland.

\section{Methodological challenges in integrating remote sensing, census and survey data to study the population-land use/cover nexus}

Despite the apparent usefulness of remotely sensed data for social purposes, Rindfuss and Stern (1998) are of the opinion that remotely sensed images have not been a popular data source for social science research. Their reasons are that, firstly, the variables of greatest interest to many social scientists are 
not readily measured from the air. Many social scientists find visible human artefacts such as buildings, crop fields, and roads less interesting than the abstract variables that explain their appearance and transformation. Secondly, social science is generally more concerned with why things happen than where they happen. Even areas of social science in which one might expect a spatial orientation are curiously a-spatial (Faust et al., 1997). It must, however, be mentioned that social scientists in contemporary times are using remotely sensed images for analysis.

Furthermore, a major challenge faces the Remote Sensing and GIS community. The problem is to link people to pixels, and to do so at the appropriate spatial and temporal scales, so that the behaviour of individuals, households and communities can be linked to changes in land use/cover and to the population, biophysical and geographical processes that serve to define the landscape in terms of composition and spatial organisation and their changes over time and space. According to Carrao and Caetano (2002), the spatial resolution of the image affects the measurement in the landscape. This challenge arises mainly from geo-referencing land use data and linking them with the Remote Sensing data. Although there is the danger of mixing up the levels of analysis (Mayhew 1997), land use/cover change trends can be easily assessed and linked to population data if the unit of analysis is the national, regional, district or municipal level. However, for a comprehension of the actual factors that influence land use at a very small level, i.e., the village level, the scale of analysis should be very small. Since that calls for a household survey, that is where the linkage between the two data sets is very difficult. Global Positioning Systems (GPS) have been used to circumvent this problem, but that only allows for smaller sample sizes due to time constraints (Rindfuss et al., 2002).

In using GPS, farmlands are geo-referenced and co-registered with the Remote Sensing image. A problem that may arise from this exercise is lack of good ground control points. Also, in some instances, farm size may be smaller than pixel size. Other problems include cloud cover on image, and error of classification during the processing of the image. It has been suggested that land use data should be made to conform to the Remote Sensing data at a common scale (Geoghegan et al., 1998). Also, population census data at for example a district level can be transformed to conform to the grid of 2.5 by 2.5 latitude-longitude cells on the satellite image (Diechmann et al., 2001). Evans and Moran (2002) have linked household survey data to Remote Sensing images with the level of aggregation being the farm. 
One other limitation of using data from census and other sources is that significant causal factors may not be included in those public data sources. Thus, causal variables at the finest level may not be available.

\section{Conclusion}

Land is an essential asset and a means to sustain livelihood. It is the ultimate source of wealth, the natural capital for production and the foundation on which civilisation is based. Land use/land cover plays an important role in global environmental change and sustainability, including response to climate change, ecosystem structure and function, species and genetic diversity, water and energy balance, and agro-ecological potential. Studying the effect of population dynamics on land use/cover globally and for that matter Ghana in the past was not so successful until the advent of Remote Sensing and Geographical Information Systems. Remote Sensing and global positioning systems (GPS) have given rise to the advent of more precise and geographically referenced data on cover and use of land, which in turn have created opportunities for improved assessments and analysis. With the aid of these new data, researchers have now started to unravel the processes that drive the cycle of land use change and resource degradation.

This study has demonstrated that even though Remote Sensing and GIS started quite late in Ghana, there have been some studies that integrate Remote Sensing, census and survey data to study the population-land use/ cover nexus. However, these studies have encountered a major methodological challenge. This challenge is merging the satellite and census data into a single data base, i.e., aggregating the land cover data to conform to the boundaries of each district or municipality used in the analysis. The paper shows that land use/cover change trends can be easily assessed and linked to population data if the unit of analysis is the national, regional, district or municipal level. However, for a comprehension of the actual factors that influence land use at a very small level, i.e. the village level, the scale of analysis should be very small. Since that calls for a household survey, that is where the linkage between the two data sets is very difficult. Global Positioning Systems (GPS) have been used to circumvent this problem, but that only allows for smaller sample sizes due to time constraints.

\section{References}

Abu, I. \& Brimah, R., 1989, 'Remote sensing coverage in Ghana', in G. T. Agyepong, J. Gyamfi-Aidoo, J. A. Allotey, \& P. W. K. Yankson, eds., Remote Sensing in Ghana, Department of Geography and Resource Development, University of Ghana, Legon, Environmental Protection Council in collaboration with National Remote Sensing Committee, pp. 18-21. 
Adjei, A. O., 1989, 'Remote sensing applications to geological problems in Ghana: past experiences, the present and the future', in G. T. Agyepong, J. GyamfiAidoo, J. A. Allotey, \& P. W. K. Yankson, eds., Remote Sensing in Ghana. Department of Geography and Resource Development, University of Ghana, Legon, Environmental Protection Council in collaboration with National Remote Sensing Committee, pp. 89-91.

Agurgo, F. B., 1989, 'An exploratory investigation into the use of Landsat imagery in forest inventory work in Ghana', in G. T. Agyepong, J. Gyamfi-Aidoo, J. A. Allotey, \& P.W. K. Yankson, eds., Remote Sensing in Ghana. Department of Geography and Resource Development, University of Ghana, Legon, Environmental Protection Council in collaboration with National Remote Sensing Committee, pp. 36-37.

Agyepong, G.T. 1989, 'A review of the development of remote sensing in Ghana', in G. T. Agyepong, J. Gyamfi-Aidoo, J. A. Allotey, \& P. W. K. Yankson, eds., Remote Sensing in Ghana. Department of Geography and Resource Development, University of Ghana, Legon, Environmental Protection Council in collaboration with National Remote Sensing Committee, pp. 38-42.

Agyili, P., 1989, 'Preliminary soil survey of an area north of Kintampo using Aerial Photographs’, in G. T. Agyepong, J. Gyamfi-Aidoo, J. A. Allotey, \& P. W. K. Yankson, eds., Remote Sensing in Ghana. Department of Geography and Resource Development, University of Ghana, Legon, Environmental Protection Council in collaboration with National Remote Sensing Committee, pp. 58-62. Alhassan, O. A-R., 1993, Deforestation and Energy Problems in Ghana, M.Phil. Thesis, Department of Geography, University of Bergen, Norway.

Amamoo-Otchere, E., 1989, 'Outline of possibilities of SPOT-1 image utilisation for resources inventorying and environmental monitoring in Ghana', in G. T. Agyepong, J. Gyamfi-Aidoo, J. A Allotey, \& P. W. K. Yankson, eds., Remote Sensing in Ghana. Department of Geography and Resource Development, University of Ghana, Legon, Environmental Protection Council in collaboration with National Remote Sensing Committee, pp. 52-57.

Amatekpor, J., 1999, Soils and Land-Use in the Volta Basin, State of the Art. Volta Basin Research Project, University of Ghana, Gold Type Press, Legon, Accra. Amuzu, A. T., 1989, 'Remote sensing application to water resources research in Ghana’, in G. T. Agyepong, J. Gyamfi-Aidoo, J. A. Allotey, \& P. W. K. Yankson, eds., Remote Sensing in Ghana. Department of Geography and Resource Development, University of Ghana, Legon, Environmental Protection Council in collaboration with National Remote Sensing Committee, pp. 29-31.

Ardayfio-Schandorf, E., 1986, The Rural Energy Crisis in Ghana: Its Implications for Women's Work and Household Survival, Geneva: ILO.

Banoeng-Yakubo, B., 1999, 'Application of remote sensing techniques and geographic information systems in lineament and fracture trace analysis to ground water exploration in the Upper West region, Ghana', in P. W. K. Yankson \& M. S. Rasmussen, eds., Remote Sensing and Geographic Information 
Systems (GIS) in Ghana: Research, Applications and Collaborations, Legon: Media Design, pp. 99-104.

Benneh, G. \& Agyepong, G. T., 1990, Land Degradation in Ghana, London: Commonwealth Secretariat/University of Ghana.

Braimoh, A. K. 2004a, 'Seasonal Migration and Land Use Change in Ghana', Land Degradation and Development, vol. 15, no.1, pp. 37-47.

Braimoh, A. K., 2004b, Modeling Land-use Change in the Volta Basin of Ghana. Ecology and Development Series, No. 14, Cuvillier Verlag, Gottingen.

Caldwell, J. C., 1965, 'Extended Family Obligations and Education: A study of an Aspect of Demographic Transition Among Ghanaian University Students', Population Studies, vol. 19, no. 2, pp. 183-199.

Carls, N., 1947, How to Read Aerial Photographs for Census Work, Washington DC: US Government Printing Office.

Carrao, H. \& Caetano, M., 2002, 'The Effect of Scale on Landscape Metrics', Paper presented at the International Society for Remote Sensing of the Environment Conference, Buenos Aires, Argentina, 8-12 April.

Codjoe, S. N. A., 2004, Population and Land Use/Cover Dynamics in the Volta River Basin of Ghana, 1960-2010. Ecology and Development Series, No. 15. Cuvillier Verlag, Gottingen.

Dale, V. H., O’Neill, R. V., Pedlowski, M. \& Southworth, F., 1993, 'Causes and Effects of Land Use Change in Central Rondonia, Brazil', PhotogrametricEngineering and Remote Sensing, vol. 59, no. 6, pp. 997-1005.

Diechmann, U., Balk, D. \& Yetman, G., 2001, Transforming Population Data for Interdisciplinary Usages: From Census to Grid, Palisades New York: CIESIN Working Paper.

Duadze, S.E. K., Adu-Prah, S., Annor, J. \& Dunyuo, S. S. B., 1999, ‘National land use and land cover mapping using satellite imagery', in P. W. K Yankson \& M. S. Rasmussen, eds., Remote Sensing and Geographic Information Systems (GIS) in Ghana: Research, Applications and Collaborations, Legon: Media Design, pp. 54-65.

Duadze, S. E. K., 2004, Land Use and Land Cover Study of the Savannah Ecosystem in the Upper West Region (Ghana) Using Remote Sensing. Ecology and Development Series, No. 16. Cuvillier Verlag, Gottingen.

Ehrlich, D., Lambin, E. F. \& Malingreau, J-P., 1997, 'Biomass Burning and Broadscale Land-cover Changes in Western Africa', Remote Sensing of Environment vol. 61, pp. 201-209.

Energy Research Group, 1989, 'Proceedings of the National Energy Symposium', Journal of Energy Research and Technology, vol. 4, pp. 5-9.

Entwisle, B., Walsh, S. J., Rindfuss, R. R. \& Chamratrithirong, A., 1998, 'Land-use/ land-cover and population dynamics, Nang Rong, Thailand', in D. Liverman, E. F. Moran, R. R. Rindfuss, \& P. C. Stern, eds., People and Pixels. Linking Remote Sensing and Social Science, Washington DC: National Academy Press, pp. 121-144. 
Estes, J. E., Jensen, J. R. \& Simonett, D. S., 1980, 'Impacts of Remote Sensing on U.S Geography’, Remote Sensing of Environment, vol. 10, pp. 43-80.

Evans, T. P. \& Moran, E. F., 2002, 'Spatial Integration of Social and Biophysical Factors Related to Landscape Change, Population and Development Review, Supplement to Vol. 28.

FAO, 2000, Global Forest Resources Assessment. FRA Working Paper No. 19.

Faust, K., Entwisle, B., Rindfuss, R. R., Walsh, S. J. \& Sawangdee, Y., 1997, 'Spatial Arrangement of Social and Economic Networks among Villages in Nang Rong, Thailand', Paper Presented at the Annual Meeting of the Sunbelt Social Network Conference, San Diego, California.

Geoghegan, J., Pritchard, L., Ogneva-Himmelberger, Y., Chowdhury, R. R., Sanderson, S. \& Turner II, B. L., 1998, 'Socializing the pixel and pixelizing the social in land-use and land-cover change', in D. Liverman, E. F. Moran, R. R. Rindfuss, \& P. C. Stern, eds., People and Pixels Linking Remote Sensing and Social Science, Washington DC: National Academy Press, pp. 51-69.

Ghana Statistical Service, 1989, 1984 Population Census of Ghana. Special Report on Localities by Local Authorities, Accra: Eddy Williams Ltd.

Ghana Statistical Service and Macro International Inc., 1999, Ghana Demographic and Health Survey, 1998, Maryland: Calverton.

Ghana Statistical Service, 2002, 2000 Population and Housing Census. Summary Report on Final Results, Accra: Medialite Co. Ltd.

Ghana Statistical Service, 2004, Ghana Demographic and Health Survey, 2003, Maryland: Calverton.

Guyer, J. \& Lambin, E., 1993, 'Land Use in the Urban Hinterland: Ethnography and Remote Sensing in the Study of African Intensification', American Anthropologist, vol. 95, no. 4, pp. 839-859.

Jensen, J. R. \& Cowen, D. C., 1999, 'Remote Sensing of Urban/Suburban Infrastructure and Socio-Economic Attributes', Photogrammetric Engineering and Remote Sensing, vol. 65, no. 5, pp. 611-622.

Kakane, V. C. K. \& Hooijer, A., 1999, 'Rainfall calibration for Ghana: the TAMSAT method', in P. W. K. Yankson \& M. S. Rasmussen, eds., Remote Sensing and Geographic Information Systems (GIS) in Ghana: Research, Applications and Collaborations, Legon: Media Design, pp. 31-37.

Koning de, G. H. J., Verburg, P. H., Veldkamp, A. \& Fresco, L. O., 1999, ‘Multi-scale Modelling of Land Use Change Dynamics in Ecuador', Agricultural Systems, vol. 61, no. 2, pp. 77-93.

Kufogbe, S. K., 1999, 'A remote sensing perspective on land use and environmental change in the Afram plains of Ghana using SPOT-XS images', in P. W. K. Yankson \& M. S. Rasmussen, eds., Remote Sensing and Geographic Information Systems (GIS) in Ghana: Research, Applications and Collaborations, Legon: Media Design, pp. 38-46.

Kyem, P. A. K., 1989, 'Remote sensing and disaster management: the case of earthquake hazard of Accra’, in G. T. Agyepong, J. Gyamfi-Aidoo, J. A. Allotey, \& P. W. K. Yankson, eds., Remote Sensing in Ghana. Department of Geography 
and Resource Development, University of Ghana, Legon, Environmental Protection Council in collaboration with National Remote Sensing Committee, pp. 45-48.

Lambin, E. F., Baulies, X., Bockstael, N., Fischer, G., Krug, T., Leemans, R., Moran,

E. F., Rindfuss, R. R., Skole, D., Turner II, B. L. \& Vogel, C., 1999, Land use and land cover change (LUCC): implementation strategy, IGBP Report no.48/ IHDP Report no. 10, ICBP, Stockholm.

Leddy, R. \& Mathur, P., 2002, 'Estimating Local Population in West Africa with

Lights, Infrastructure, Other', Paper presented at the 2002 ESRI International User's Conference, 8-12 July, San Diego, California.

Mayhew, S., 1997, A Dictionary of Geography, New York: Oxford University Press. Mensah, F. K. \& Nyamekye, A., 1999, 'The use of remote sensing for road map updating: a pilot study for the Greater Accra region', in P. W. K. Yankson \& M. S. Rasmussen, eds., Remote Sensing and Geographic Information Systems (GIS) in Ghana: Research, Applications and Collaborations, Legon: Media Design, pp. 50-53.

Mertens, B. \& Lambin, E. F., 1997, 'Spatial Modelling of Deforestation in Southern Cameroon’, Applied Geography, vol. 17, no. 2, pp. 143-162.

Mertens, B., Sunderlin, W. D., Ousseynou N. \& Lambin, E. F., 2000, 'Impact of Macroeconomic Change on Deforestation in South Cameroon: Integration of Household Survey and Remotely-Sensed Data', World Development, vol. 28, no. 6, pp. 983-999.

Meyer, W. B., 1995, 'Past and Present Land Use and Land Cover in the United States of America’, Consequences, vol.1, no. 1, pp. 25-33.

Millington, A., Al-Hussein, S. \& Dutton, R., 1999, 'Population Dynamics, Socioeconomic Change and Land Colonisation in Northern Jordan, With Special Reference to the Badia Research and Development Project Area', Applied Geography, vol. 19, no. 4, pp. 363-84.

Moran, E. F., 1982, 'An assessment of a decade of colonization in the Amazon Basin', in J. Heming, ed., Change in the Amazon Basin: The Frontier after a Decade of Colonization, Manchester: University of Manchester, pp. 92-102. Moran, E. F. \& Brondizio, E., 1998, 'Land use change after deforestation in Amazonia’, in D. Liverman, E. F. Moran, R. R. Rindfuss, \& P. C. Stern, eds., People and Pixels. Linking Remote Sensing and Social Science, Washington DC: National Academy Press, pp. 94-120.

Nketia, K. S., Hagan, E. \& Addo, S. T., 1988, The Charcoal Cycle in Ghana: A Baseline Study, UNDP/National Energy Board Project.

Pfaff, A., 1997, 'Spatial Perspectives on Deforestation in the Brazilian Amazon:

First Results and a Spatial Research Agenda’, Paper Presented in Conference on Research Transformations in Environmental Economics. Policy Design in Responses to Global Change, Durham, N.C., May, 5-6.

Population Reference Bureau, 2004, Population Data Sheet, Washington, DC. Quattrochi, D. A. \& Goodchild, M. F., eds., 1997, Scale in Remote Sensing and GIS, New York: Lewis Publishers. 
Rahman, M. M. \& Csaplovics, E., 1999, Assessing Tropical Deforestation in Southern Chittagong, Bangladesh Using Remote Sensing, Dresden University of Technology, Germany: Institute of International Forestry and Forest Products.

Rindfuss, R. \& Stern, P., 1998, 'Linking remote sensing and social science: the need and the challenges’, in D. Liverman, E. F. Moran, R. R. Rindfuss, \& P. C. Stern, eds., People and Pixels. Linking Remote Sensing and Social Science, Washington DC: National Academy Press, pp. 1-27.

Rindfuss, R., Entwisle, B., Walsh, S. J., Prasartkul, P., Sawangdee, Y., Crawford, T. W. \& Reade, T., 2002, 'Continuous and discrete: where they have met in Nang Rong, Thailand', in S. Walsh \& K. Crews-Meyer, eds., Linking People, Place and Policy: A GIScience Approach, Boston: Kluwer Academic Press.

Sever, T. L., 1998, 'Validating prehistoric and current social phenomenon upon the landscape of the Peten, Guatemala', in D. Liverman, E. F. Moran, R. R. Rindfuss, \& P. C. Stern, eds., People and Pixels. Linking Remote Sensing and Social Science, Washington DC: National Academy Press, pp. 145-163.

Skole, D. L. \& Tucker, C. J., 1993, 'Tropical Deforestation, Fragmented Habitats, and Adversely Affected Habitat in the Brazilian Amazon: 1978-1988’, Science, vol. 260, pp. 1905-1910.

Tufour, K., 1989, 'Population, Forests and Woodlands in Ghana', Paper Presented at the National Workshop on Population, Resources, Environment and Development in Ghana, Accra, October 25-27.

USDA Forest Service, 1989, Interim Resource Inventory Glossary, Washington, DC.

Veldkamp, A. \& Fresco, L. O., 1997, 'Reconstructing Land Use Drivers and their Spatial Scale Dependence for Costa Rica, 1973 and 1984', Agricultural Systems, vol. 55, pp. 19-43.

Verburg, P. H., Veldkamp, A. \& Fresco, L. O., 1999a, 'Simulation of Changes in the Spatial Pattern of Land use in China', Applied Geography, vol. 19, no. 3, pp. 213-235.

Verburg, P. H., Veldkamp, A. \& Bouma, J., 1999b, 'Land Use Change Under Conditions of High Population Pressure: The Case of Java', Global Environmental Change, vol. 9, no. 4, pp. 303-312. 